\title{
Automated Lecture Time-tabling System for Tertiary Institutions
}

\author{
Jumoke Soyemi \\ Dept. of Computer Science \\ Federal Polytechnic, Ilaro
}

\author{
John Akinode \\ Dept. of Computer Science \\ Federal Polytechnic, Ilaro
}

\author{
Samson Oloruntoba \\ Dept. of Computer Science \\ Federal Polytechnic, Ilaro
}

\begin{abstract}
The need to automate the manual process of lecture time tabling system in higher institution of learning cannot be set aside. Despite the fact that several other administrative sectors of most institution have been automated, lecture time-tabling is still done manually because of its inherent problems. Planning lecture time table is an administrative responsibility that demands enormous attention and effort from any institution because of its constraint satisfaction problem. The Federal Polytechnic Ilaro, the case study in this research operates a central time tabling system implemented by a set up committee members within the institution, which makes it more difficult in getting a flawless lecture scheduling. This manual time-tabling system used in the institution is time consuming and energy sapping which leads to loss of information, general apathy, clashes and wastage of resources. This research is targeted at ameliorating the above stated challenges. The main aim of the study is to develop an automated lecture time-tabling system to provide convenience in scheduling lecture time-table, reducing time constraints in fixing the courses and venues and reducing the risk of omission of courses and clashes of halls and lecturers. The scope of work is limited to space allocation for lectures and merging of similar courses for a particular lecturer. We also administered questionnaire to sample staff, committee members and student opinion on the existing system and the new system to be developed. The data gathered was analyzed and based on the analysis; the new system (automated time tabling system) will be the best method in tackling the lapses experienced by the old system (manual time table).
\end{abstract}

\section{General Terms}

Computer Application

\section{Keywords}

Lecture time table, Manual time-tabling system, Automated Time-tabling system, Institution.

\section{INTRODUCTION}

Lecture time-tabling system is a system of scheduling lecture time and available resources so as to maximize such resources [1], [2]. It is one the most important yet time consuming task done periodically in any academic institution of learning. Therefore lecture time table should be carefully assigned into appropriate timeslot for students, lecturers and lecture halls based on constraints [3]. The timetable scheduling in the Federal Polytechnic, Ilaro is done manually by the Standing committee of the Academic board for lecture time table. The lecture time-tabling is done centrally and not on school (faculty) basis or departmental basis. Data are collected from various departments in each school for the preparation. The timetable process is in three phases namely: Data collection from departments, where each department will supply the various courses which will include the course title, course code, contact hour (lectures and practical), course unit and the lecturer to take them. The second phase is the analysis of the provided data where the data supplied by the departments are analyzed with the available space [hall sizes]. The last phase is the Lecture time scheduling. Based on the analysis, the lecture time-table is produced with three outputs vis-à-vis: Hall time-table [omnibus/main control], Departmental Input and Lecturers time-table [control II]. In scheduling the lecture time table, the following constraints must be taken into consideration; No student can attend more than one lecture at a time, No lecturer can teach more than one course per time and lecture hall cannot be assigned to more than one particular course at a time.

\section{LITERATURE REVIEW}

\subsection{Manual Time-tabling Generation}

Timetable scheduling is an NP-hard problem. NP-hard stands for Non Polynomial Hard and means that there is no specific algorithm which can be used for creating timetables, as constraints for timetables vary from institute to institute. The manual lecture time-tabling system requires considerable time and effort with a lot of paperwork. The process involves assigning courses, lecturers and resources such as lecture halls to timeslots subject to constraints [4]. The committee saddled with the responsibility of manual time-tabling generation are usually faced with numerous challenges ranging from erroneous computation, clashes in lecture halls, omission of courses just to mention a few. It has been noted that space management in educational institutions is more critical compared to other institutions [5]. Therefore, management of space and facilities within an organization is paramount and must be dealt with efficiently. A study by Ibrahim and colleagues also noted that the space management for institute of higher learning is very critical and therefore, space and facilities management have to be the main agenda and need to be managed efficiently [6].

According to Burke and friends, the problem of timetabling is the problem of assigning the various resources to the meetings in a consistent manner [7]. Timetable involves a set of incident $\mathrm{E}=\{\mathrm{e} 1, \mathrm{e} 2, \ldots \ldots \ldots . \mathrm{en}\}$ meeting a set of time to the said incident $\mathrm{T}=\{\mathrm{t} 1, \mathrm{t} 2, \ldots . . \mathrm{ts}\}$. The set of place where the incident occurred $P=\{p 1, p 2 . ., p m\}$ and a set of agents in conduct of the incident $\mathrm{A}=\{\mathrm{a} 1, \mathrm{a} 2, \ldots \mathrm{an}\}$ for example lecturers. The formal definition for timetable is given in details in the event that the following resources and time slot exist as follows:

$$
\begin{aligned}
& \text { A set of lecturers }\{\mathrm{t} 1, \mathrm{t} 2 \ldots \mathrm{tn}\} \\
& \text { A set of courses }\{\mathrm{c} 1, \mathrm{c} 2, \ldots . \mathrm{cm}\} \\
& \text { A set of lecture-halls }\{\mathrm{r} 1, \mathrm{r} 2, \ldots . \mathrm{rq}\} \\
& \text { A set of time }\{\mathrm{p} 1, \mathrm{p} 2, \ldots . \mathrm{ps}\}
\end{aligned}
$$


This attempts to arrange classes suitable to the lecture such that no lecturer will be allocated in two classes at the same time [8]. This approach is scheduling timetable may solve several constriction such as courses that have various time, joint courses, the distribution of courses in a week and lecture halls required.

\subsection{Automated Time-tabling Generation}

With the increase in the number of student population, new programmes being mounted and additional lecture halls, an automated time-tabling system is required to cater for this increase. Most of the time-tabling problems belong to the class of NP-hard problems, as no deterministic polynomial algorithm exists. Timetable definition is the total schedule of specific lectures attended by a group of students in an institution and the lecturer at a specific time. It also requires specific resources such as lecture halls and so on [8].

Automated methods used to solve time-tabling include Tabu Search, Simulated Annealing, Evolutionary Algorithms and Artificial Intelligence [9]. There are a number of papers within [10] that deal specifically with Genetic Algorithm methods of automated time-tabling. Another study [11] noted that only on particularly complex or resource starved timetabling problems do Evolutionary Algorithms including GAs-Genetic Algorithms begin to outperform methods such as hill-climbing. Professional software currently available for Automated Timetabling lacks the generality required by different institutions. This can mean that code needs adjustment or lengthy training and installation programs before it can be implemented at an institution which it was not intentionally written for.

\section{SYSTEM DESIGN}

The first step in developing the software was to gather the required information from the committee involved in manual time table preparation. Data obtained include the number of lectures halls, number of lecturers, courses with hours of lectures and practical involved. The manual process was analyzed and represented using Algorithm-Flowchart to understand the flow of operation. This enabled us to understand the flow of operation during the development phase of the project. System analysis and documentation of "To be" application was then carried out. The Business Process for the manual time table (As It Is) and automated time table (The To $\mathrm{Be}$ ) and the Business process Model for the proposed time tabling system are represented in the figures 1,2 and 3 respectively below. The system is the minimum operating system required. Also Adobe PDF reader or any other PDF reading software was used. The design of different forms required for user interaction was developed. The interface was developed to be user friendly. The development of a model that represents the structure of the database and the interaction of the application with the database was carried out. For the Controller, we designed the logic and the implementation of different processes for the application system. We integrated the developed modules into a single unit -the software package. We then went ahead to test and validate the application output, efficiency and flow.

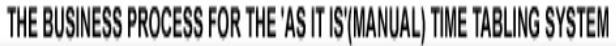

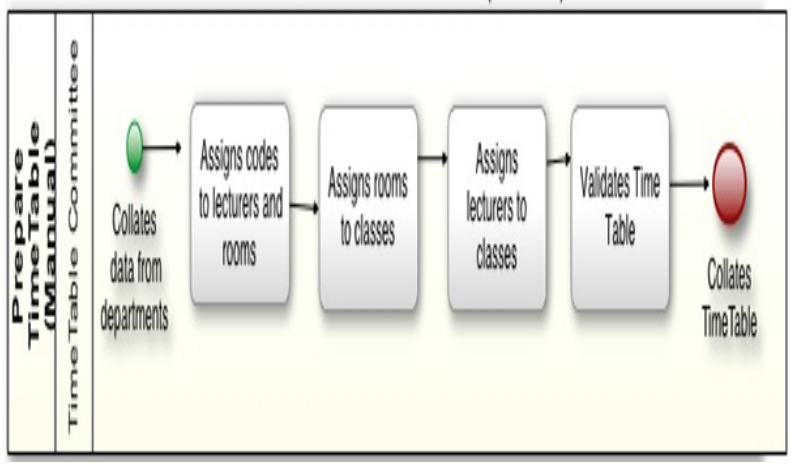

Fig 1: Existing Manual Process of Time-tabling System

THE BUSNESS PROCESS FOR THE 'TO BE' TIME TABLING SYSTEM

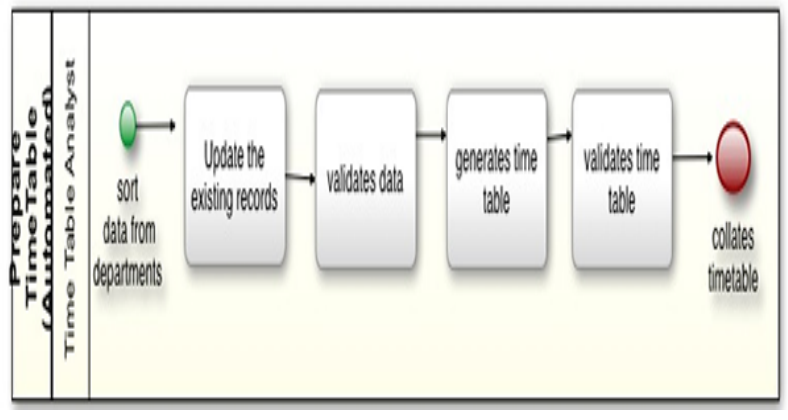

Fig 2: Time table Analysis Model

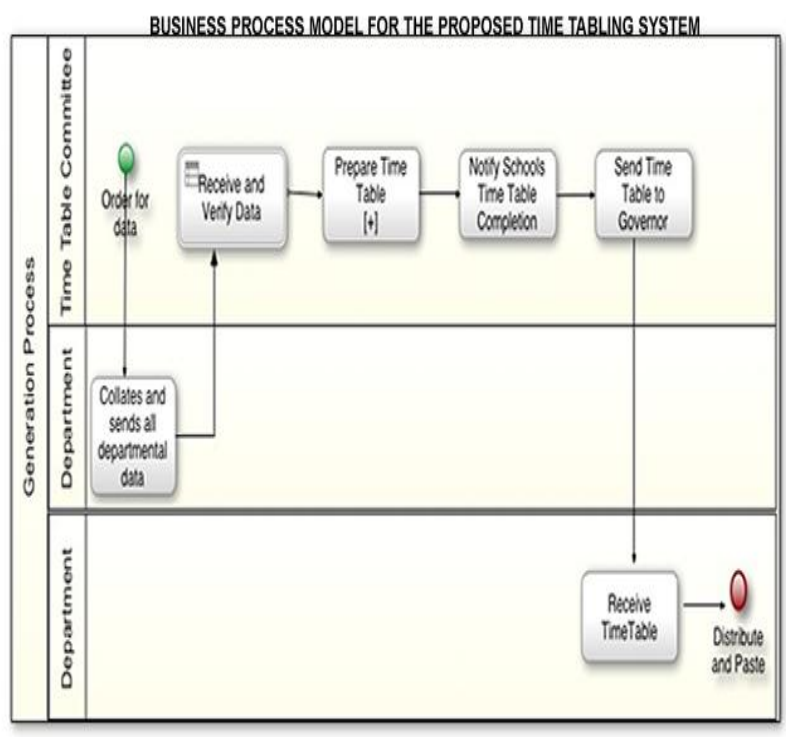

Fig 3: The Proposed Model for Automated Time-tabling System

\section{SYSTEM IMPLEMENTATION AND STATISTICAL ANALYSIS}

\subsection{Software Implementation}

Several constraints were taken into consideration in the software implementation. The case study in this research utilizes a centralized lecture time tabling system, meaning that lecture scheduling for the school is done centrally. A number of constraints were taken into consideration among which are; No student can attend more than one lecture at a time, No 
lecturer can teach more than one course per time and lecture hall cannot be assigned to more than one particular course at a time. In addition courses with same course code, title and at the same class level can be merged together to maximize space utilization. Figure 4 is a snapshot of 'Assign Lecturer to Courses' module; table 5 is a module indicating where additional halls/venues can be added to existing venues. Figure 6 is a 'Generation of Timetable' module where the actual allocations of courses are done by the software based on constraints set. Figure 7 is a module where the generated time table can be obtained and finally figure 8 is the result of the lecture time table generated and downloaded in PDF format.

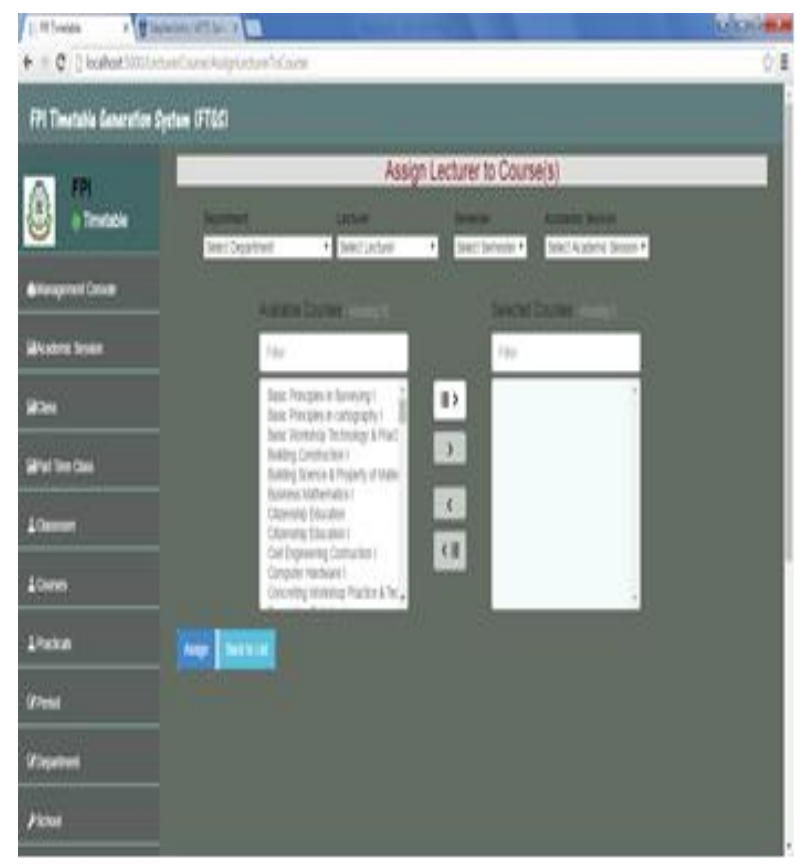

Figure 4: Course to Lecturer Assignment Module

The module above is where Courses are assigned to Lecturers per semester. More courses could be added and new lecturers too.

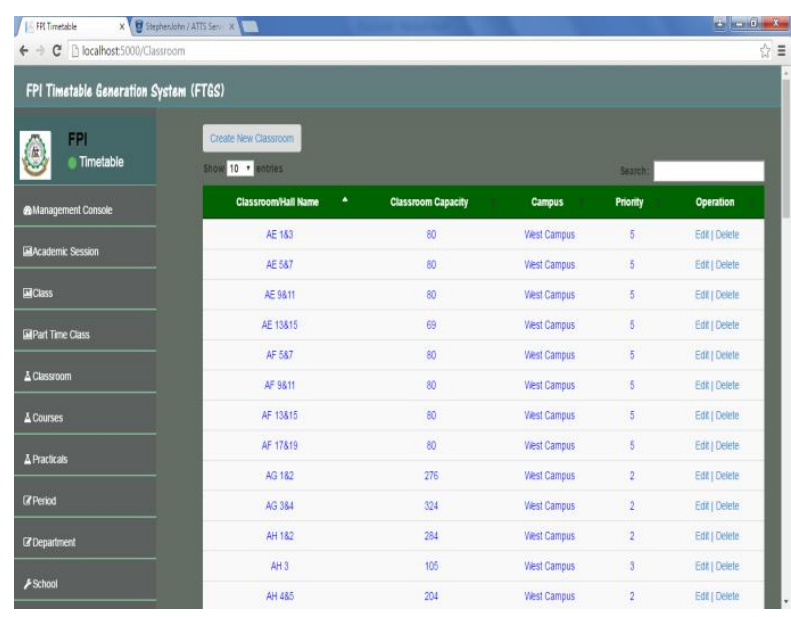

Figure 5: Classroom/Hall Capacity Module

The module above holds all the available lecture halls in the institution of our case study together with the capacity of such halls. The software thus allocates lecture halls based on the class size for maximum utilization of limited resources. The software is also able to merge classes ( 2 or 3 ) into a lecture hall as long as the course title, course code and class level are the same and there is available class capacity that can hold such merged classes.

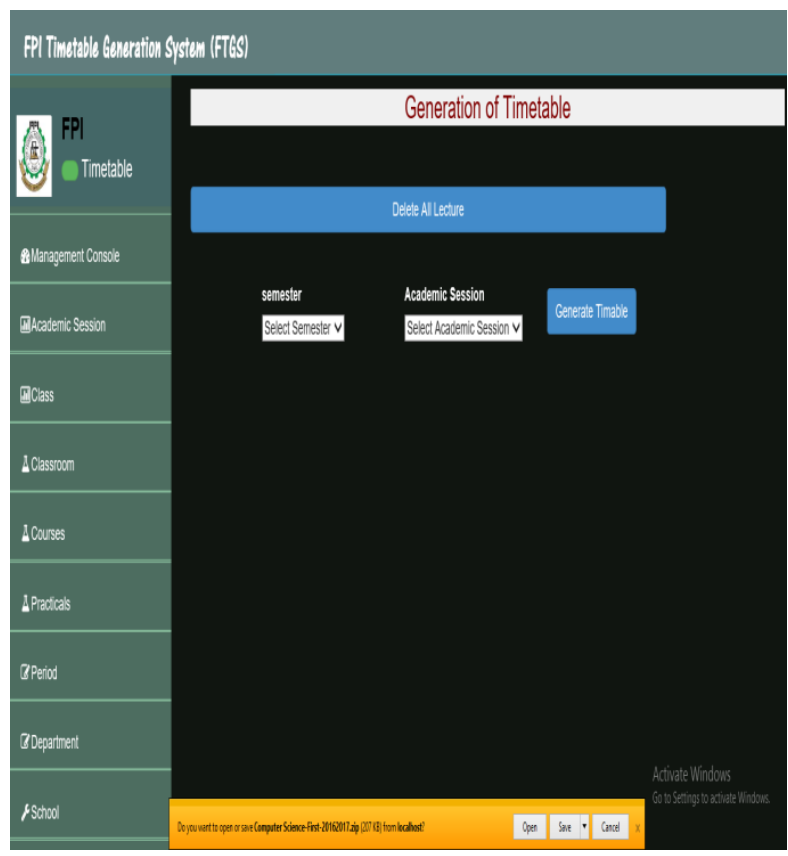

Figure 6: Lecturer Time table Generation Module

After allocation of courses in figure 4, figure 6 is the module where the actual time table is generated by the software by applying all the constraints stated earlier.

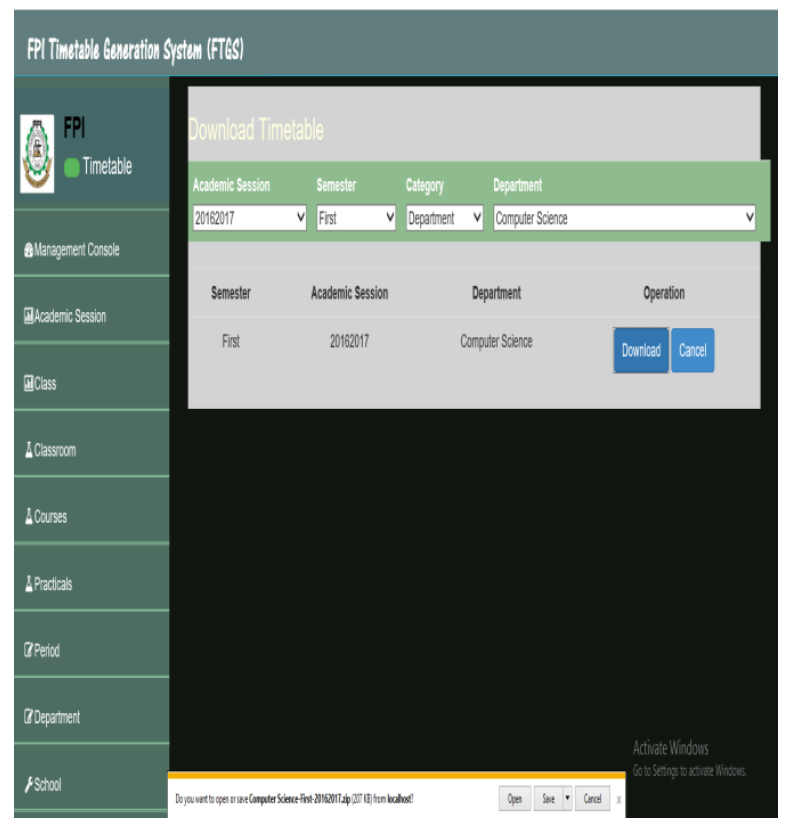

Figure 7: Module for Lecture Time table Download

Figure 7 is a module where the generated time table could be downloaded by specifying whether it should download based on departmental basis, school basis or for the whole institution. The Tab 'Academic session' selects the session to be downloaded. 'Semester tab' is where to specify either first or second semester and 'class tab' selects the department and 
the class level such as CSI - which means Computer Science department 100 level, MSII - means Mathematics and Statistics department 200 level and so on.

\begin{tabular}{|c|c|c|c|c|c|c|c|c|}
\hline ( I & & & $\begin{array}{l}\text { FEDEER } \\
\text { P.M.B 50. }\end{array}$ & $\begin{array}{l}\text { AL POLY } \\
\text { ILARO, OGUN }\end{array}$ & $\begin{array}{l}\text { TECHNI } \\
\text { STATE, NIGE }\end{array}$ & $\begin{array}{l}\text { C,ILARC } \\
\text { RIA }\end{array}$ & & \\
\hline Cassisin & & Senserefix & & $\begin{array}{l}\text { Acodenic Tmeted } \\
\text { kaskis }\end{array}$ & sionsent & & Destititent & \\
\hline apersost & иманиа & ниминии & мананы & 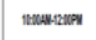 & нания & เมตнมี & MRSUN & แอง \\
\hline wow & & ands $x$ & & asand ond & & & & \\
\hline IEEW & 206 & & casent & & andiz & $\cos 24$ & & \\
\hline resest & & & & & & & 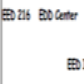 & \\
\hline Heser & & & & & & & & \\
\hline matr & & 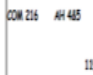 & & & & & & as sun Lifet \\
\hline sureer & & & & & & & & \\
\hline 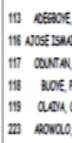 & & & & & & & & \\
\hline
\end{tabular}

Figure 8: Generated and Downloaded Lecture time table in PDF format

This is a PDF sample of software generated and downloaded lecture time table showing allocations of courses to lecturers and lecture halls. This figure also displays a list of lecturers to teach various courses and the code given to such lecturers for identification.

\subsection{Statistical Analysis}

Two hundred and fifteen questionnaires were administered to the respondents which comprises of the "time tabling committee, the school lecturers, and the students" out of which two hundred (about 93\%) were returned. The administered questionnaires were in three sections viz; demographic information of the respondents, components of time tabling scheduling and perception of respondents on automated time-tabling system. The three sections were filled by the fifteen (15) committee members of the school manual time table while only two sections (demographic information and perception of centralized time tabling) were filled by other respondents. The research data was analyzed using Statistical Package for Social Sciences, version 20.

Questionnaires were distributed randomly among the four schools in the institution; School of Pure and Applied Science, School of Engineering, School of Environmental and School of Management. From table 1 field survey, there is an indication that $47(23.5 \%)$ were from school of Applied Sciences, 50 (25\%) were from school of Engineering, $47(23.5 \%)$ from school of environmental studies and 56(28\%) were from school of management studies. The respondents cut across all the school departments viz; Mathematics and Statistics, Computer Science, Science Laboratory Technology, Food Science and Technology, Nutrition and Diatetics, Civil Engineering, Mechanical Engineering, Electrical Engineering, Computer Engineering, Building Technology,
Estate Management and Valuation, Quantity Surveying, Surveying and Geo-Informatics, Urban and Regional Planning, Accountancy, Banking and Finance, Business Administration and Management, Marketing, Insurance, Taxation and General Studies department as evidenced in figure 8 .

Table 1. Demographic Information of respondents

\begin{tabular}{|l|l|l|l|}
\hline \multicolumn{1}{|c|}{} & Frequency & Percentage\% \\
\hline \multirow{5}{*}{ Gender } & Male & 88 & 44 \\
& Female & 112 & 56 \\
& Total & $\mathbf{2 0 0}$ & $\mathbf{1 0 0}$ \\
\hline Status & Single & 140 & 70 \\
& Married & 50 & 25 \\
& Divorced & 10 & 5 \\
& Total & $\mathbf{2 0 0}$ & $\mathbf{1 0 0}$ \\
\hline \multirow{5}{*}{ School } & Applied Science & 47 & 23.5 \\
& Engineering & 50 & 25 \\
& Environmental & 47 & 23.5 \\
& sciences & 56 & 28 \\
& Management & $\mathbf{2 0 0}$ & $\mathbf{1 0 0}$ \\
& Sciences & & \\
& Total & \multicolumn{2}{|l}{} \\
\hline
\end{tabular}

Source: Field Survey, 2016.

The analysis made in figure 9 shows that majority of the respondents was from the school of management studies.

\section{School Distribution of Respondents}

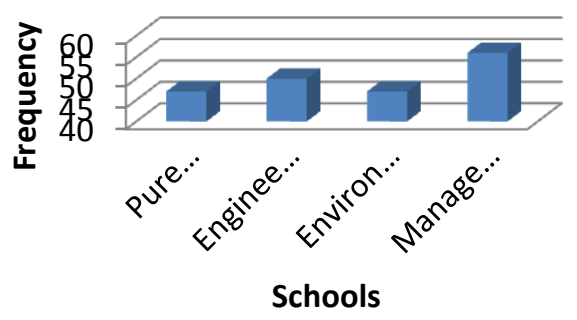

\section{Figure 9: Bar Chart showing School distribution of Respondents}

Table 2 is the analysis on the response of time tabling committee on "components of time tabling scheduling" which indicates that about $73.3 \%$ of the committee opined that time table data collection and verification are always done, $60 \%$ opined that producing institution time table is done always and all the respondents also opined that the institution time table is always updated, $26.7 \%$ opined that resources, venues and teaching staff are occasionally deployed in an efficient and effective manner, while $73.3 \%$ were of the opinion that the analyzed item is always deployed. It was also of the committees opinion that lecture timetable are considered and confirmed as appropriate to the demands of the course. 
Table 2: Components of Time Tabling Scheduling

\begin{tabular}{|c|c|c|c|c|}
\hline $\begin{array}{l}\mathbf{S} / \mathbf{N} \\
\mathbf{0}\end{array}$ & & & $\begin{array}{l}\text { Frequenc } \\
\text { y }\end{array}$ & $\begin{array}{l}\text { Percentag } \\
\text { e }\end{array}$ \\
\hline 1 & $\begin{array}{l}\text { To what } \\
\text { extent is } \\
\text { time table } \\
\text { data } \\
\text { collection } \\
\text { and } \\
\text { verificatio } \\
\text { n done? }\end{array}$ & $\begin{array}{l}\text { Always } \\
\text { Occasionall } \\
\text { y } \\
\text { Total }\end{array}$ & $\begin{array}{l}11 \\
4 \\
15\end{array}$ & $\begin{array}{l}73.8 \\
26.7 \\
\mathbf{1 0 0 . 0}\end{array}$ \\
\hline 2 & $\begin{array}{l}\text { Producing } \\
\text { Institution } \\
\text { Time table } \\
\text { should be } \\
\text { done }\end{array}$ & $\begin{array}{l}\text { Always } \\
\text { Occasionall } \\
\text { y } \\
\text { Total }\end{array}$ & $\begin{array}{l}9 \\
6 \\
\mathbf{1 5}\end{array}$ & $\begin{array}{l}60 \\
40 \\
\mathbf{1 0 0 . 0}\end{array}$ \\
\hline 3 & $\begin{array}{l}\text { To what } \\
\text { extent is } \\
\text { the } \\
\text { Institution } \\
\text { Time table } \\
\text { updated? }\end{array}$ & $\begin{array}{l}\text { Always } \\
\text { Total }\end{array}$ & $\begin{array}{l}15 \\
15\end{array}$ & $\begin{array}{l}100.0 \\
\mathbf{1 0 0 . 0}\end{array}$ \\
\hline 4 & $\begin{array}{l}\text { Resources, } \\
\text { venues of } \\
\text { lectures, } \\
\text { and } \\
\text { teaching } \\
\text { staff are } \\
\text { deployed } \\
\text { in an } \\
\text { efficient } \\
\text { and } \\
\text { effective } \\
\text { manner }\end{array}$ & $\begin{array}{l}\text { Always } \\
\text { Occasionall } \\
\text { y } \\
\text { Total }\end{array}$ & $\begin{array}{l}11 \\
4 \\
15\end{array}$ & $\begin{array}{l}73.3 \\
26.7 \\
\mathbf{1 0 0 . 0}\end{array}$ \\
\hline 5 & $\begin{array}{l}\text { Lectures } \\
\text { time table } \\
\text { are } \\
\text { considered } \\
\text { and } \\
\text { confirmed } \\
\text { as } \\
\text { appropriat } \\
\mathrm{e} \text { to the } \\
\text { demand of } \\
\text { the course }\end{array}$ & $\begin{array}{l}\text { Always } \\
\text { Occasionall } \\
\text { y } \\
\text { Total }\end{array}$ & $\begin{array}{l}13 \\
2 \\
15\end{array}$ & $\begin{array}{l}86.7 \\
13.3 \\
\mathbf{1 0 0 . 0}\end{array}$ \\
\hline
\end{tabular}

\section{Source: Field Survey, 2016}

Based on the analysis of the research study, it is pertinent to note that time tabling scheduling is a pre-requisite for effective implementation of any school lecture time table. This is evidenced from figure 9 below.

\section{Perception of Respondents on Components of Time Tabling Schedulling}

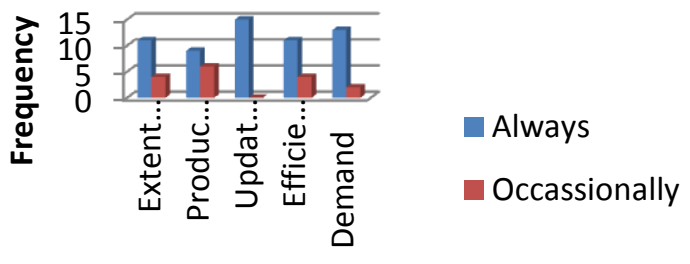

Items

Figure 10: Component Bar Chart showing the perception of respodents on component time tabling scheduling

Table 3: Perception of Respondents on Automated Time Tabling Scheduling

\begin{tabular}{|c|c|c|c|c|}
\hline $\begin{array}{l}\mathbf{S} / \mathbf{N} \\
\text { o }\end{array}$ & & & $\begin{array}{l}\text { Frequen } \\
\text { cy }\end{array}$ & $\begin{array}{l}\text { Percenta } \\
\text { ge }\end{array}$ \\
\hline 1 & $\begin{array}{l}\text { Do you } \\
\text { think the } \\
\text { automated } \\
\text { method of } \\
\text { time tabling } \\
\text { scheduling } \\
\text { is } \\
\text { appropriate }\end{array}$ & $\begin{array}{l}\text { Yes } \\
\text { No } \\
\text { Total }\end{array}$ & $\begin{array}{l}169 \\
31 \\
200\end{array}$ & $\begin{array}{l}84.5 \\
15.5 \\
\mathbf{1 0 0 . 0}\end{array}$ \\
\hline 2 & $\begin{array}{l}\text { Do you } \\
\text { think this } \\
\text { method will } \\
\text { be } \\
\text { convenient } \\
\text { and easy to } \\
\text { use? }\end{array}$ & $\begin{array}{l}\text { Yes } \\
\text { No } \\
\text { I don't know } \\
\text { Total }\end{array}$ & $\begin{array}{l}155 \\
29 \\
16 \\
\mathbf{2 0 0}\end{array}$ & $\begin{array}{l}77.5 \\
14.5 \\
8 \\
\mathbf{1 0 0 . 0}\end{array}$ \\
\hline 3 & $\begin{array}{l}\text { Do you } \\
\text { think the } \\
\text { manual } \\
\text { system of } \\
\text { timetabling } \\
\text { scheduling } \\
\text { is } \\
\text { appropriate } \\
\text { in this } \\
\text { dispensation } \\
\text { ? }\end{array}$ & $\begin{array}{l}\text { Yes } \\
\text { No } \\
\text { I don't know } \\
\text { Total }\end{array}$ & \begin{tabular}{l|l}
15 \\
174 \\
11 \\
$\mathbf{2 0 0}$
\end{tabular} & $\begin{array}{l}7.5 \\
87 \\
5.5 \\
\mathbf{1 0 0 . 0}\end{array}$ \\
\hline 4 & $\begin{array}{l}\text { Should a } \\
\text { particular } \\
\text { unit be } \\
\text { responsible } \\
\text { for time } \\
\text { tabling } \\
\text { scheduling? }\end{array}$ & $\begin{array}{l}\text { Yes } \\
\text { No } \\
\text { I don't know } \\
\text { Total }\end{array}$ & $\begin{array}{l}139 \\
33 \\
28 \\
\mathbf{2 0 0}\end{array}$ & $\begin{array}{l}69.5 \\
16.5 \\
14 \\
\mathbf{1 0 0 . 0}\end{array}$ \\
\hline 5 & $\begin{array}{l}\text { Are your } \\
\text { timetable } \\
\text { schedule } \\
\text { always } \\
\text { flawless? }\end{array}$ & $\begin{array}{l}\text { Yes } \\
\text { No } \\
\text { I don't know } \\
\text { Total }\end{array}$ & $\begin{array}{l}25 \\
161 \\
14 \\
\mathbf{2 0 0}\end{array}$ & $\begin{array}{l}12.5 \\
80.5 \\
7 \\
\mathbf{1 0 0 . 0}\end{array}$ \\
\hline 6 & $\begin{array}{l}\text { Has this } \\
\text { manual } \\
\text { system been }\end{array}$ & $\begin{array}{l}\text { Yes } \\
\text { No } \\
\text { Total }\end{array}$ & $\begin{array}{l}128 \\
72 \\
\mathbf{2 0 0}\end{array}$ & $\begin{array}{l}64 \\
36 \\
\mathbf{1 0 0 . 0}\end{array}$ \\
\hline
\end{tabular}




\begin{tabular}{|c|c|c|c|c|}
\hline & $\begin{array}{l}\text { dealing with } \\
\text { intensive } \\
\text { teaching } \\
\text { arrangement } \\
\text { s } \\
\text { effectively? }\end{array}$ & & & \\
\hline 7 & $\begin{array}{l}\text { Have you } \\
\text { ever } \\
\text { experienced } \\
\text { clashes of } \\
\text { courses and } \\
\text { halls? }\end{array}$ & $\begin{array}{l}\text { Yes } \\
\text { No } \\
\text { Total }\end{array}$ & $\begin{array}{l}35 \\
165 \\
200\end{array}$ & $\begin{array}{l}17.5 \\
82.5 \\
\mathbf{1 0 0 . 0}\end{array}$ \\
\hline 8 & $\begin{array}{l}\text { Do you } \\
\text { think delay } \\
\text { in time } \\
\text { tabling } \\
\text { scheduling } \\
\text { is as a result } \\
\text { of manual } \\
\text { process of } \\
\text { preparation? }\end{array}$ & $\begin{array}{l}\text { Yes } \\
\text { No } \\
\text { Total }\end{array}$ & $\begin{array}{l}171 \\
29 \\
200\end{array}$ & $\begin{array}{l}85.5 \\
14.5 \\
\mathbf{1 0 0 . 0}\end{array}$ \\
\hline 9 & $\begin{array}{l}\text { Would it be } \\
\text { best if an } \\
\text { automated } \\
\text { method of } \\
\text { time tabling } \\
\text { scheduling } \\
\text { be engaged? }\end{array}$ & $\begin{array}{l}\text { Yes } \\
\text { Total }\end{array}$ & $\begin{array}{l}200 \\
\mathbf{2 0 0}\end{array}$ & $\begin{array}{l}100 \\
\mathbf{1 0 0 . 0}\end{array}$ \\
\hline 10 & $\begin{array}{l}\text { Are you of } \\
\text { the opinion } \\
\text { that with } \\
\text { automated } \\
\text { time } \\
\text { tabling, } \\
\text { clashes will } \\
\text { be } \\
\text { eradicated }\end{array}$ & $\begin{array}{l}\text { Yes } \\
\text { Total }\end{array}$ & $\begin{array}{l}200 \\
\mathbf{2 0 0}\end{array}$ & $\begin{array}{l}100 \\
\mathbf{1 0 0 . 0}\end{array}$ \\
\hline 11 & $\begin{array}{l}\text { Will this } \\
\text { new method } \\
\text { make time } \\
\text { tabling } \\
\text { reliable, } \\
\text { effective } \\
\text { and } \\
\text { efficient? }\end{array}$ & $\begin{array}{l}\text { Yes } \\
\text { No } \\
\text { I don't know } \\
\text { Total }\end{array}$ & $\begin{array}{l}131 \\
48 \\
21 \\
\mathbf{2 0 0}\end{array}$ & $\begin{array}{l}65.5 \\
24 \\
10.5 \\
\mathbf{1 0 0 . 0}\end{array}$ \\
\hline 12 & $\begin{array}{l}\text { Do you } \\
\text { think with } \\
\text { the new } \\
\text { system, } \\
\text { time table } \\
\text { can be } \\
\text { changed } \\
\text { once it is } \\
\text { published? }\end{array}$ & $\begin{array}{l}\text { Yes } \\
\text { No } \\
\text { I don't know } \\
\text { Total }\end{array}$ & $\begin{array}{l}86 \\
20 \\
94 \\
\mathbf{2 0 0}\end{array}$ & $\begin{array}{l}43 \\
10 \\
47 \\
\mathbf{1 0 0 . 0}\end{array}$ \\
\hline 13 & $\begin{array}{l}\text { If } \\
\text { scheduling } \\
\text { is carried } \\
\text { out } \\
\text { automaticall } \\
\text { y, do you } \\
\text { think there } \\
\text { will be any } \\
\text { responsibilit } \\
\text { y for } \\
\text { timetabling }\end{array}$ & $\begin{array}{l}\text { Yes } \\
\text { No } \\
\text { I don't know } \\
\text { Total }\end{array}$ & $\begin{array}{l}63 \\
122 \\
15 \\
\mathbf{2 0 0}\end{array}$ & $\begin{array}{l}31.5 \\
61 \\
7.5 \\
\mathbf{1 0 0 . 0}\end{array}$ \\
\hline
\end{tabular}

\begin{tabular}{|c|c|c|c|c|}
\hline & $\begin{array}{l}\text { committee } \\
\text { members? }\end{array}$ & & & \\
\hline 14 & $\begin{array}{l}\text { How will } \\
\text { you rate the } \\
\text { overall } \\
\text { performanc } \\
\text { e of manual } \\
\text { time-tabling } \\
\text { scheduling? }\end{array}$ & $\begin{array}{l}\text { Highly } \\
\text { satisfactory } \\
\text { Satisfactory } \\
\text { Neutral } \\
\text { Total }\end{array}$ & $\begin{array}{l}20 \\
108 \\
35 \\
\mathbf{2 0 0}\end{array}$ & $\begin{array}{l}10 \\
47 \\
17.5 \\
\mathbf{1 0 0 . 0}\end{array}$ \\
\hline 15 & $\begin{array}{l}\text { How would } \\
\text { you rate the } \\
\text { overall } \\
\text { performanc } \\
\text { e of the } \\
\text { time-tabling } \\
\text { committee } \\
\text { in terms of } \\
\text { prompt } \\
\text { delivery? }\end{array}$ & $\begin{array}{l}\text { Highly } \\
\text { satisfactory } \\
\text { Satisfactory } \\
\text { Unsatisfacto } \\
\text { ry } \\
\text { Total }\end{array}$ & $\begin{array}{l}50 \\
105 \\
42 \\
\mathbf{2 0 0}\end{array}$ & $\begin{array}{l}25 \\
52.5 \\
100.0\end{array}$ \\
\hline 16 & $\begin{array}{l}\text { How would } \\
\text { you rate the } \\
\text { effectivenes } \\
\text { s of of } \\
\text { operating an } \\
\text { automated } \\
\text { time-tabling } \\
\text { scheduling }\end{array}$ & $\begin{array}{l}\text { Highly } \\
\text { satisfactory } \\
\text { Satisfactory } \\
\text { Neutral } \\
\text { Total }\end{array}$ & $\begin{array}{l}104 \\
37 \\
59 \\
200\end{array}$ & $\begin{array}{l}52 \\
29.5 \\
9.5 \\
\mathbf{1 0 0 . 0}\end{array}$ \\
\hline
\end{tabular}

Source: Field Survey, 2016.

Table 3 in line with figure 11 indicates the perception of respondents on automated timetabling scheduling. About $169(84.5 \%)$ opined that automated timetabling is appropriate out of which $155(77.5 \%)$ opined that the method will be convenient and easy to use; $174(87 \%)$ opined that manual system of timetabling is inappropriate in this modern dispensation, 139(69.5\%) were of the opinion that a particular unit should be responsible for timetabling scheduling, $161(80.5 \%)$ were of the opinion that their timetable is not always flawless, $36 \%$ of the respondents were of the opinion that manual system has not been dealing with intensive teaching arrangements effectively of which about 165 totalling $82.5 \%$ opined that they have never experienced clashes of course and halls. the results is a good indication that automated time tabling will be the best method to be adopted in an higher learning environment.

However, about $171(85.5 \%)$ of the total respondents opined that delay in timetabling scheduling is as a result of manual process of preparation but would be best if an automated method is engaged as opined by all the respondents because of the clashes it would eradicate. In addition, the automated method will make timetabling reliable, efficient and effective as opined by $65.5 \%$ of all the respondents while $10.5 \%$ don't know what its outcome would be. It was also opined by $43 \%$ of the respondents that the new system timetable can be changed once it is published while $61 \%$ of the total respondents were of the opinion that there would be no responsibility for timetabling committee members if scheduling is carried out automatically. 


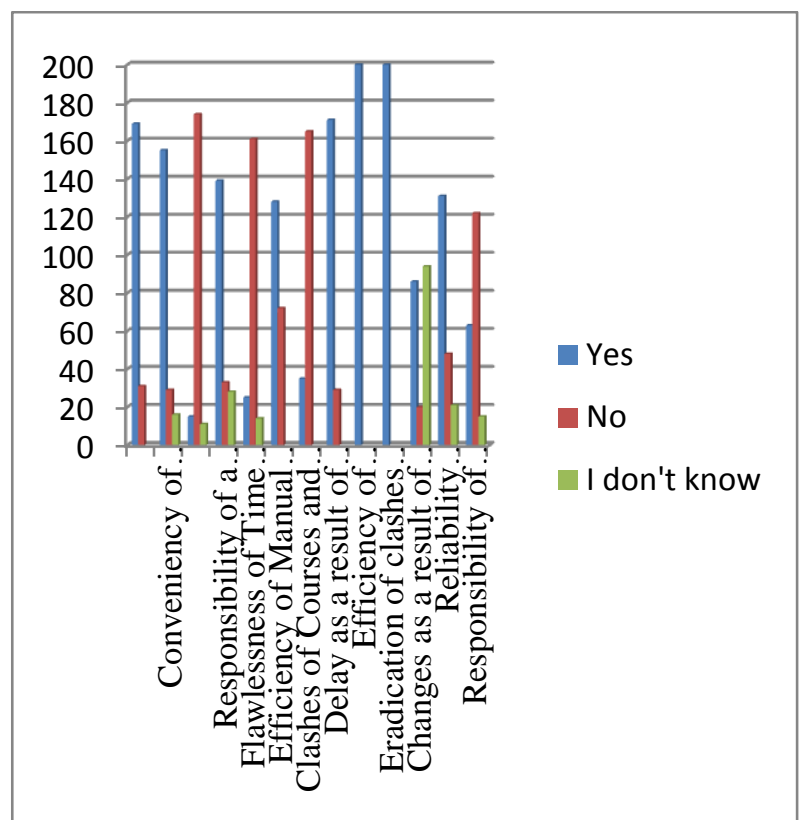

Figure 11: Component Bar Chart showing the perception of respondents on Time tabling Scheduling

$x^{2}=\sum_{i=1}^{n} \frac{\left(o_{i}-e_{i}\right)^{2}}{e_{i}}$

Where;

$$
\begin{aligned}
& \chi^{2} \text { is the chi-square test statistic } \\
& O_{i} \text { is the observed frequency } \\
& e_{i} \text { is the expected frequency } \\
& \sum \text { is the summation sign }
\end{aligned}
$$

The critical value, $\chi_{\text {tab }}^{2} \Rightarrow \chi_{\alpha,(r-1)(c-1)}$

Where;

$$
\begin{aligned}
& \alpha=\text { level of significance } \\
& (\mathrm{r}-1)(\mathrm{c}-1)=\text { Degree of freedom }
\end{aligned}
$$

Decision rule: Reject $\mathrm{H}_{0}$ if $\chi_{\text {cal }}^{2}$ is greater than $\chi_{\text {tab }}^{2}$ at $\alpha$ level of significance, otherwise, accepts $\mathrm{H}_{0}$. For the purpose of this research work, the hypotheses was tested at $95 \%$ confidence level i.e. $\alpha=0.05$

$\mathrm{H}_{0}$ : Automated timetabling scheduling is not significantly

\begin{tabular}{|c|c|c|c|c|c|}
\hline & \multicolumn{3}{|c|}{ RESPONSE LEVEL } & \multirow{3}{*}{ Total } \\
\hline & & YES & NO & & \\
\hline & & & & $\begin{array}{l}\text { DON'T } \\
\text { KNOW }\end{array}$ & \\
\hline \multirow{17}{*}{ 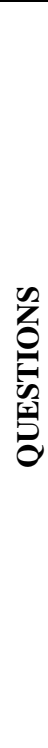 } & Do you think & 169 & 31 & 0 & 200 \\
\hline & & & 109.0 & & \\
\hline & Automated & & & & \\
\hline & method & & & & \\
\hline & of time table & & & & \\
\hline & is appropriate? & & & & \\
\hline & Do you think & & & & \\
\hline & the manual & 15 & 174 & 11 & 200 \\
\hline & system of & 82.33 & 109.0 & 8.67 & \\
\hline & timetabling & & 0 & & \\
\hline & scheduling is & & & & \\
\hline & appropriate in & & & & \\
\hline & Will this new & & & & \\
\hline & method make & 131 & 48 & 21 & 200 \\
\hline & time tabling & 82.33 & 109.0 & 8.67 & \\
\hline & reliable, & & 0 & & \\
\hline & effective and & & & & \\
\hline & enticie & 247 & 327 & 26 & 600 \\
\hline & I otal & 241 & 521 & 20 & \\
\hline
\end{tabular}
efficient, reliable and effective in Nigeria Higher Institution

$\mathrm{H}_{1}$ : Automated timetabling scheduling is significantly efficient, reliable and effective in Nigeria Higher Institution.
Table 4 Cross tabulation table.

Expected counts are printed below observed counts

Table 5 Computed Result

\begin{tabular}{|l|l|l|l|l|}
\hline $\begin{array}{l}\text { Chi- } \\
\text { square }\end{array}$ & DF & $\begin{array}{l}\text { Critical } \\
\text { Value }\end{array}$ & P-Value & Remark \\
\hline 260.886 & 4 & 9.488 & 0.000 & Reject $\mathrm{H}_{0}$ \\
\hline
\end{tabular}

From the chi-square analytical method, we observed that the calculated result is greater than the critical value at the $\alpha=$ 0.05 level of significance i.e. $59.674>9.488$. Therefore, we reject the null hypothesis and conclude that automated timetabling scheduling is significantly efficient, reliable and effective in Nigeria Higher Institutions. This can also be evidenced from the P-value of 0.000 which also serve as an indication of rejecting $\mathrm{H}_{0}$ since it is less than $\alpha=0.05$ level of significance.

The plotted graph of figure 12 below justify the significance of the tested hypothesis in addition to the opinion of the respondents on the overall performance of manual and automated time tabling scheduling. The perception on general satisfaction indicates that $36 \%$ were "highly satisfied" with manual time tabling scheduling while $52 \%$ was observed and recorded for its automated counterpart. 


\section{Perception of respondents on overall performance of Time Tabling Scheduling}

$$
200 \text { Iजz }
$$

Overall performance of manual time tabling scheduling

Overall performance of committee in terms of prompt delivery

\section{Figure 12: Component Bar Chart showing perception of respondents on overall performance of Time Tabling Scheduling}

Based on the empirical analysis of this research study, it is significant enough to conclude that automated time tabling technique is appropriate and also serves as the best method to be adopted in tackling the lapses of its manual process counterpart in this modern dispensation as evidenced by the opinion of the respondents and the hypothesis tested.

\section{CONCLUSION}

At the end of the software development, an automated time tabling system was generated to overcome the shortcoming of manual time tabling system. This automated system will simplify the manual process, ensure optimum allocation of resources and reduce the risk of omission of courses and clashes of halls and lecturers. The application software developed can be adapted and customized in other institutions of learning to ease the burden of the manual process. Also based on the statistical analysis of this research study, automated time tabling system will be the best method to be adopted in tackling the lapses of its manual counterpart as evidenced by the opinion of the respondents and the hypothesis tested. This study therefore recommends the full deployment of this prototype and its implementation which will ease the burden of the manual process of time-tabling system and improve the academic activities of the institution at large.

\section{ACKNOWLEDGMENTS}

This research was supported by TETFUND Grant.

\section{REFERENCES}

[1] Burke E. K. and Petrovic S. Recent research directions in automated timetabling $[\mathrm{J}]$ European Journal of Operational Research, 2002, 140(2):.266-280.

[2] Chowdhary A. Kakde P. Dhoke S. Ingle S. Rushiya R. and Gawande D. Timetable generation system. [J] International Journal of Computer Science and Mobile Computing, 2014 3(2).

[3] Bayo M.I. and Izah O. M. Towards the Implementation Electronic Lecture Timetable System at Ambrose Alli University [J] Applied Science Research Journal. 2014, 1(2): 27-37.

[4] Zhou $X$ and Zhong M. Single-track train timetabling guaranteed optimality: Branch-and-bound algorithms with enhanced lower bounds. [J] Transportation Research Part B: Methodological. 2007, 41(3)320-341.

[5] Tay L. and Ooi J.T. Facilities management: a Jack of all trades? [J]. Facilities, 2001, 19 v (10)357-363.

[6] Ibrahim I. Yusuff W.Z. and Sidi. N.S. Space Charging Model: Cost analysis on classrooms in higher education institutions. [J] Procedia-Social and Behavioral Sciences, 2011, 28:.246-252.

[7] Burke E. Elliman D. and Weare R. The automation of the timetabling process in higher education. [J] Journal of Educational Technology Systems, 1995, 23(4):353-362.

[8] de Werra D. Some combinatorial models for course scheduling. Practice and Theory of Automated Timetabling, 1996, pp.296-308.

[9] Burke E., Practice and Theory of Automated Timetabling. [C] In: Proceedings of 1st International Conference, Edinburgh, UK, and August 29-September 1,1995 .

[10] Bambrick L. Lecture Timetabling Using Genetic Algorithms. Department of Electrical and Computer Engineering, The University of Queensland, 1997, pp.29. 